адреналовою та імунної системами в розвитку оксидативного стресу як компонента природженої на набутої імунної відповіді.

Ключові слова: запалення, оксидативний стрес, ремоделювання серця та судин, гіпертензія, ренінангіотензинова система, імунний статус.

\title{
THE ROLE OF INFLAMMATION AND OXIDATIVE STRESS IN CARDIOVASCULAR PATHOLOGY
}

\section{T.V. Talayeva, V.V. Shishkin, L.L. Vavilova}

Abstract. The paper is devoted to an analysis of the problem of the significance and mechanisms of inflammation and oxidative stress participation in the development of cardiovascular pathology, first of all - in heart and vascular wall damaging and remodeling and in the development of arterial hypertension. An interrelation is traced between the reninangiotensin, sympathoadrenal and immune systems in the development of oxidative stress as a component of innate and adaptive immune responses.

Key words: inflammation, oxidative stress, cardiac and vascular remodelling, hypertension, renin-angiotensin system, immune status.

National Scientific Center "N.D.Straszhesko Institute of Cardiology" of Ukrainan National Academy of Medical Sciences (Kyiv),

National Medical University (Odessa)

Рецензент - проф. В.К. Тащук
Buk. Med. Herald. - 2013. - Vol. 17, № 1 (65). - P. 156-163

Надійшла до редакції 10.12.2012 року

\section{ПОРУШЕННЯ ФУНКЦІОНАЛЬНОГО СТАНУ ЕНДОТЕЛІЮ У ХВОРИХ НА ПЕПТИЧНУ ВИРАЗКУ ШЛУНКА ТА ДВАНАДЦЯТИПАЛОЇ КИШКИ, ПОСДНАНУ 3 МЕТАБОЛІЧНИМ СИНДРОМОМ}

Буковинський державний медичний університет, м. Чернівці

Резюме. В оглядовій статті узагальнено основні відомості про роль ендотеліальної дисфункції при пептичній виразці шлунка та дванадцятипалої кишки в процесі виникнення і становлення метаболічного синдрому. Наведено дані про вплив ендотеліальних чинників на розвиток ремоделювання судинної стінки при виразці шлунка і дванадцятипалої кишки та метаболічному синдромі.

Ключові слова: ендотеліальна дисфункція, пероксидне окиснення ліпідів, оксид азоту, метаболічний синдром, виразкова хвороба шлунка, дванадцятипала кишка, гіпертонічна хвороба, гіперглікемія.

ними, у 16,7 \% випадків ісеА - позитивними, у $12,5 \%$ випадків - babA - позитивними штамами H.pylori. Причому ерозивно - виразкові захворювання шлунка та ДПК у 75,0-100,0 \% випадків асоційовані з СаgА - позитивними серотипами H.pylori. При інфікуванні CagA - i iceA - позитивними H.pylori психосоматичний статус страждає більшою мірою, ніж у решти хворих [4].

Клінічно значимими на сьогоднішній день визнані цитотоксичні штами CagA i vacA, які також мають широкий діапазон екстрадигестивних проявів.

В осіб, інфікованих $\mathrm{CagA}$, асоційованих штамами H.pylori, спостерігається вища активність антрального гастриту і більший ступінь вираженості кишкової метаплазії. Вони спричиняють виражену лімфоцитарну реакцію зі збільшенням кількості лімфоїдних фолікулів [5]. позитивними, у 83,3 \% випадків - vacA - позитив- 
Без сумніву, наявність Н. pylori $€$ чинником ризику виникнення рецидиву ВХ. Рецидив ДВ протягом року при інфікуванні Н. pylori трапляється в 75-80 \% випадків. Високий ступінь обсіювання i велика кількість продуктів життєдіяльності бактерій гальмують загоєння і епітелізацію виразки [6].

При тяжкому рецидивному перебігу ВX переважно персистують Cag-A та vac-А позитивні штами Н. pylori [7].

Дискусійним є питання щодо частоти поєднання пептичної виразки шлунка і дванадцятипалої кишки та метаболічного синдрому.

В індустріально розвинених країнах серед населення, старшого віку від 30 років, поширеність метаболічного синдрому (МС) становить приблизно 10-20 \%. Комплекс метаболічних порушень серед чоловіків частіше трапляється в середньому віці, а в жінок його частота зростає з початком менопаузального періоду [8]. Для МC характерні не тільки підвищення АТ, особливо вночі, але і його варіабельність упродовж доби. Спостерігається навантаження міокарда тиском, порушується двофазний циркадний ритм коливання АТ. Оскільки в більшості $(66,7 \%)$ пацієнтів із МС виявляється недостатнє зниження АТ вночі і висока його варіабельність, слід вважати цю групу потенційно небезпечною щодо виникнення фатальних серцево-судинних ускладнень, навіть порівняно з хворими на есенційну АГ $[9,10]$.

Недостатньо вивченим залишаються зміни функціонального стану ендотелію та системи гемостазу при ВХШ та ДПК у поєднанні з МС.

Порушення ендотеліальної функції судин патогенетично пов'язане 3 розвитком інсулінорезистентності (IP), яка спостерігається в більшості хворих на гіпертонічну хворобу (ГХ) [7]. Накопичений експериментальний та клінічний матеріал, а також епідеміологічні дослідження, що продемонстрували підвищення рівня інсуліну серед хворих на ГХ, безумовно, вказують на IP як важливу патогенетичну ланку ГХ [11].

Причинно-наслідкові зв'язки ендотеліальної дисфункції (ЕД) та IP залишаються дискутабельними. У багатьох дослідженнях продемонстровано, що ЕД $є$ наслідком тих механізмів, що лежать в основі IP - гіперглікемії, артеріальної гіпертензії (АГ), дисліпідемії. При гіперглікемії в ендотеліальних клітинах активується фермент протеїнкіназа-С, який збільшує проникність судинних клітин для білків і порушує ендотелійзалежну вазодилатацію (ЕЗВД) [12].

Окрім того, гіперглікемія активує процеси пероксидного окиснення ліпідів, продукти якого пригнічують судинорозширювальну функцію ендотелію. При АГ відбувається порушення архітектоніки ендотеліальних клітин, підсилення продукції вазоконстрикторного ендотеліну-1, судинне ремоделювання зі зменшенням еластичності судин. Отже, наведені механізми, підвищуючи проникність ендотелію та експресію адгезивних молекул, знижують ЕЗВД [13].

Інші дослідники вважають, що ЕД призводить до розвитку IP внаслідок порушення трансендотеліального транспорту інсуліну [14]. Без сумніву, IP та ЕД, у тому числі і продукція $\mathrm{NO}$, міцно пов'язані між собою і формують патологічне "замкнуте коло". Попри нез'ясованість ще багатьох причинно-наслідкових зв'язків у патогенезі ЕД, беззаперечним $є$ те, що ЕД є першою ланкою в розвитку атеросклерозу, пов'язаного із синдромом IP.

Встановлено, що в осіб із гіперінсулінемією без цукрового діабету (ЦД), навіть за відсутності абдомінального ожиріння, гіперхолестеринемії, гіпертригліцеридемії, АГ та куріння, спостерігалися вищі рівні захворюваності на IXC і смертності від інфаркту міокарда [15]. Таким чином, є всі підстави розглядати гіперінсулінемію як незалежний фактор ризику IXC в осіб без ЦД.

Механізми розвитку IP досить складні і вивчені недостатньо, тому подальше дослідження $\epsilon$, беззаперечно, актуальним.

За наявності судинно-ендотеліальної дисфункції порушується мікроциркуляція з утворенням трофічних порушень, зниження кровотоку слизової оболонка шлунка (СОШ) та ДПК одним з істотних факторів ульцерогенезу. Як правило, локальне зниження регіонарного кровотоку, розлад мікроциркуляції, що супроводжується розвитком тканинної гіпоксії, призводять до порушень регенерації СО 3 подальшою активізацією катаболічних процесів i переважанням апоптозу. Ці ж порушення зумовлюють розвиток ускладненого перебігу ВХ [16].

Адекватний кровотік може виявити виражений протективний вплив на СОШ і СО ДПК, а гіпоксія, що виникає при порушенні кровотоку, призводить до глибокого геморагічного некрозу 3 утворенням ерозій і виразок.

Величина кровотоку в слизовій оболонці шлунка складає 30 мл/хв/100г, є критичною при ульцерогенезі. Зниження кровотоку в рубцеводеформованій $\mathrm{CO} з$ персистувальною запальною інфільтрацією є предиктором рецидиву ВХ [17].

Серед основних чинників, які спричинюють ішемію СО, можна виділити такі:

1) переважання кишкової метаплазії та атрофії в СО у хворих старшої вікової групи;

2) атрофія ворсинок, а часто і крипт, оскільки в нормі мікроциркуляція в них становить відповідно близько 25-30 \% від тотального кишкового кровотоку [18].

Шкідливу дію чинять хемотоксини H.pylori, що призводить до порушення синтезу NO. Ерадикація Н. pylori супроводжується дворазовим підвищенням експресії соматостатину. Наявність Н. pylori в СОШ у хворих на ПВ поглиблює ендотеліальну дисфункцію, про що свідчить статистично вірогідне підвищення рівнів ЕT-1, NO та регіонарного кровотоку в черевному стовбурі у Нрпозитивних осіб порівняно з відповідними показниками в пацієнтів за відсутності Нр-інфекції. Ендотеліальна дисфункція може розглядатися як один із факторів, що сприяють виразкоутворенню. Протимікробні властивості NO, що продукується СОШ та СО ДПК у разі запалення, спричиненого $\mathrm{H}$. pylori, можливо, могли б 
відігравати позитивну роль щодо сповільнення розвитку патологічного процесу [19]. Виявлена підвищена експресія індуцибельної NO-синтази (iNOS) у випадку інфікування Н. pylori. Проте Н. pylori за допомогою супероксиду, аргінази та інгібіторів i-NOS блокує синтез NO, тим самим «ухиляється» від імунної відповіді та «захищається» від запальної реакції [20]. У свою чергу, Н. pylori резистентний до протимікробної дії NO за наявності оксидази в клітинній мембрані бактерії. Зазначається, що NO, утворений синтетичними NO-генераторами, призводить до швидкого дозозалежного морфологічного перетворення H. pylori [21]. Зі спіральної форми, яка реплікується, мікроорганізм трансформується в таку, що не реплікується, але життєздатну кокоподібну форму. Відомо, що тільки спіральні мікроорганізми здатні індукувати секрецію епітеліальними клітинами слизової оболонки шлунка інтерлейкіну-8. Ця конверсія може сприяти зменшенню активності запального процесу.

Наведені дані дають можливість припускати, що збільшення активності i-NOS, яке спостерігається у разі гастриту, призводить до морфологічної зміни в потенційно неактивну, але життєздатну форму Н. pylori [22].

За фізіологічних умов NO діє як ендогенний медіатор, що сприяє підтриманню цілісності та відновленню тканин, виявляє гастропротекторні властивості, запобігаючи ураженню слизової оболонки шлунка різноманітними пошкоджувальними факторами. У відповідь на фізичну та хімічну стимуляцію в ендотелії на короткий період під впливом ацетилхоліну, брадикініну, 5-гідрокситриптаміну, аденілових нуклеотидів підвищується утворення NO [23]. У макрофагах, нейтрофілах $є$ кальційнезалежна індуцибельна NO-синтаза, за активації якої відбувається тривале підвищення вмісту NO. Під його впливом відбувається вазодилатація, підсилюється судинна проникність, розвивається набряк та спостерігається прогресування запальної реакції. Високі концентрації NO $\epsilon$ однією з причин розвитку багатьох уражень травного каналу, зокрема пептичної виразки [24].

Окремі фактори, до яких належить ендотелін-1 (ЕТ-1), у нормі практично не синтезуються, проте їх концентрація істотно зростає в разі стимуляції ендотелію [25].

Важливими є дослідження щодо виявлення впливу підвищеного рівня глюкози крові на регуляцію виділення та дію ЕТ-1. Вивчення впливу високого рівня глюкози на чутливість рецепторів ЕТ-1 також призвело до суперечливих результатів. Інкубація культури лейоміоцитів аорти за високого рівня глюкози призводила до підвищення зв'язування ЕТ-1, але не чутливості до нього. На противагу цьому в перицитах, що інкубувались in vitro за високого рівня глюкози, спостерігалася тенденція до зменшення кількості рецепторів ЕТ-1. Показано, що зміна плазмової концентрації ЕТ-1 та судинна відповідь на його дію 3 індукованим ЦД залежать від тривалості захворювання [26].
ЦД 2-го типу часто супроводжується гіперінсулінемією. За проведення інсулінотерапії в пацієнтів із ЦД 1-го типу спостерігаються коливання рівня інсуліну в крові. Відомо, що останній підвищує експресію гена ЕТ-1 в ендотеліальних клітинах, ще спричиняє вивільнення ними ЕT-1 у фізіологічних умовах. У зв'язку з цим важливими $\epsilon$ дослідження значення цього ефекту у випадку різних патологічних станів. Доведено також вплив інсуліну на зміну чутливості тканин до ЕТ1 на рецепторному та пострецепторному рівні. У разі інкубації лейоміоцитів аорти in vitro 3 підвищенням концентрації інсуліну збільшується експресія рецепторів ЕТ-1. За тривалого спостереження із ЦД, індукованим стрептозотоцином (in vivo), під впливом інсуліну підвищується кількість рецепторів ЕТ-1 у різних тканинах. Навпаки, у разі інкубації гладеньком'язових клітин 3 інсуліном упродовж короткого періоду спостерігається пригнічення судинної реакції у відповідь на дію ЕТ1 [27]. Скорочувальна здатність у відповідь на дію ЕТ-1 знижена за наявності фізіологічних концентрацій інсуліну. Отже, вплив інсуліну на чутливість непосмугованих м'язів до ET-1 in vitro залежить від тривалості впливу інсуліну та ступеня ушкодження ендотелію. Інсулін діє як модулятор ЕТ-1, ЕТ-рецепторів, ЕT-1-опосередкованої відповіді in vitro та in vivo.

Однак не встановлено, чи мають патофізіологічне значення спровоковані інсуліном зміни активності ЕТ-1 у разі ЦД. Водночас $є$ свідчення стимуляції ЕТ-1 секреції інсуліну шляхом прямого впливу на острівці Лангерганса.

Ендотеліальна дисфункція, що спричиняється гіперглікемією, полягає також у зменшенні продукції NO, інактивації його вільними радикалами, підвищенні продукції ендотеліальних вазоконстрикторних речовин, що протидіють судинним ефектам NO. Деякі дослідження показують, що базальна і стимульована секреція NO істотно підвищувались у клітинах, що піддавалися впливу високих концентрацій глюкози [28].

Дані про стан ендотелійзалежної релаксації у випадку ЦД $\epsilon$ суперечливими. Порушення ендотелійзалежної релаксації суттєво впливає також i на активність ЕТ-1. Відомо, що ендотеліальний фактор релаксації пригнічує вивільнення ЕТ-1. Крім того, блокада рецепторів ЕT-1 відновлює функцію ендотелійзалежної релаксації на тваринних моделях атеросклерозу, що свідчить про дію ЕT-1 як інгібітора NO за патологічних станів [29]. У випадку прогресування ЦД вивільнення та дія ЕТ-1 залежать від змін рівня NO та функції ендотелію. Порушення ендотеліальної регуляції судинного тонусу та ремоделювання судин, зумовлені проатерогенними порушеннями рівноваги між ендотеліальними медіаторами, такими як NO, простациклін, ET-1, тромбоксан А2, тромбоцитарний фактор росту $\beta$ i трансформувальний фактор росту, сприяють розвитку гіпертензії, вазоспазму та ішемії, а в кінце- 
вому підсумку - макроангіопатії [30]. Крім того, протромботичні порушення ендотеліального контролю гемостазу, фібринолізу та функції тромбоцитів можуть передувати судинним порушенням. Отже, порушення функціонального стану ендотелію, що характеризуються змінами продукції та дії важливих БАР (ЕТ, NO та деяких інших), є одним із механізмів розвитку ускладнень ЦД [31].

При ВХШ та ДПК спостерігаються істотні зміни внутрішньоорганного судинного русла, які виражаються у розвитку венозної гіперемії та гіпертензії при порушенні відтоку крові $з$ ділянок виразки. Виникаюча компенсаторна реакція в артеріальному руслі у вигляді спазму судин зменшує приплив крові і сприяє скиданню крові в обхід капілярного русла. Це, з одного боку, покращує артеріальне кровопостачання «інтактної» зони, сприяючи репаративним і компенсаторним iii можливостям, 3 іншого - погіршує трофічні процеси в зонах виразок.

Гемомікроциркуляторні розлади і порушення судинної проникності спричиняють розвиток i активацію склеротичних процесів у стінках кровоносних судин і периваскулярної сполучної тканини як у зоні виразки, так і поза нею, що з часом призводить до перебудови судинного русла органів, погіршення метаболізму структур стінок шлунка і ДПК, сприяючи ульцерогенезу і хронічного перебігу хвороби [32].

Виявлені зміни мікроциркуляторного русла в зоні виразкового дефекту:

-по-перше, це зміни конфігурації просвіту капілярів внаслідок набрякання цитоплазми i просвіту складок відростків ендотеліоцитів, різко звужують просвіт капіляра;

-по-друге, розпушення і лізис базального шару, що призводять до порушення проникності судин і цілісності капілярної стінки;

-по-третє, переважання катаболічних процесів на внутрішньоклітинному рівні над синтетичними, що супроводжується розпадом ендотеліоцитів.

У непошкодженій слизовій оболонці шлунка і в краї виразки найнижчий кровотік спостерігається в гострий період. При загоєнні виразки він поступово досягає нормальних значень, а в краї виразки перевищує такий у гострій стадії, з інтактною СО і в ділянці кратера.

Ішемія, 3 одного боку, $\epsilon$ причиною ВX, 3 іншого - ВХ призводить до істотних патологічних змін мікроциркуляторного русла, що значно потенціює вихідну ішемію і спричиняє розвиток ускладнень ВХ.

Відомо, що ВХШ та ДПК супроводжується такими змінами СОШ: набряк (85,7 \% осіб), обмежене запалення (42,8 \% осіб), дифузне запалення (1/5 частина осіб) та геморагічні зміни, що мали місце в 5,7 \% випадків. Дифузне запалення СО ДПК відзначено у 82,8 \% осіб, рубцеві деформації - у 45,7 \%, геморагічні зміни - у 14,3 \% осіб [33]. При цьому гастроезофагеальний рефлюкс було відзначено у 22,8 \% осіб, а дуоденогастраль- ний - у 42,8 \%. Аналіз даних внутрішньошлункової рН-метрії дозволив констатувати ФІ $\mathrm{pH}$ у межах 0,9-2,2 у 30 \% пацієнтів, а коливання $\mathrm{pH}$ у межах 3,7-7,5 було відзначено у $20 \%$ осіб. Визначено також суттєве підвищення вмісту кінцевих продуктів пероксидного окиснення ліпідів - МА (10,9 $\pm 0,5$ мкмоль/л), що істотно перевищувало референтну норму $(4,9 \pm 0,2$ мкмоль/л відповідно; $\mathrm{p}<0,001)$ і свідчило про суттєву активацію процесів ліпопероксидації [34]. Зазначені явища супроводжувалися підвищенням рівнів циркулюючих імунних комплексів (ЦІК): рівень загальних ЦІК

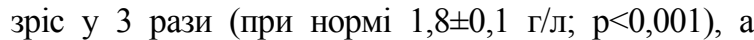
рівень середньомолекулярної, найбільш патогенної фракції ЦІК, перевищував референтні значення практично в 4 рази $(\mathrm{p}<0,001)$, тобто був наявний синдром метаболічної інтоксикації [35].

Окрім того, у сироватці крові виявлялися вірогідно ( $<0,001)$ підвищені рівні ФНП- $\alpha$ у 10 разів (при нормі 24,5 $\pm 3,2$ пг/мл) та ІЛ-10 у 7 разів (референтна норма $31,0 \pm 2,2$ пг/мл; $<<0,001$ ). Отже, для хворих на ВХШ та ДПК характерними є підвищені рівні фактора некрозу $\alpha$ (ФНП- $\alpha)$ та інтерлейкіну-10 (ІЛ-10) у сироватці крові, причому активація їх синтезу відбувається в умовах інтенсифікації ліпопероксидації та поєднується із синдромом метаболічної інтоксикації [36].

Рівень прозапального цитокіну інтерлейкіну6 у пацієнтів основної групи на 74,3 \% перевищував рівень у пацієнтів групи порівняння $(\mathrm{p}<0,05)$. На ушкоджуючу дію надлишкових ліпідів крові ендотелій реагує синтезом вазоконстрикторів, а також активацією ренін-ангіотензинової систем [37]. Ангіотензин II є основним антагоністом оксиду азоту, що не тільки пригнічує його синтез, а й перетворює вже синтезований оксид азоту в токсичний пероксинітрит, який руйнує ендотеліоцити і окиснює ліпопротеїдів низької щільності (ЛПНЩ), які стають шкідливими для організму [1]. Всі зазначені вище процеси призводять до хронічного імунного запалення в організмі і призводять до розвитку та прогресування цілого ряду системних патологій (АГ, атеросклерозу, ішемічної хвороби серця, включаючи інфаркт міокарда, мозкових інсультів) [38].

Окиснені ЛПНЩ та прозапальні цитокіни збільшують проникність ендотелію, призводять до проліферації м'язових клітин у стінці судини, що потовщує комплекс інтима-медіа у 2-3 рази, підвищує жорсткість артерій і сприяє розвитку резистентної до лікування АГ [39].

Однією $з$ причин ендотеліальної дисфункції може бути гіперхолестеринемія. Показано істотне збільшення синтезу NOS-3 супероксидрадикалів при гіперхолестеринемії [40]. Саме зниження рівня активного NO зумовлює вплив окиснених ЛПНЩ на ендотелій, що призводить до виділення медіаторів запалення [41].

\section{Література}

1. Середюк Н.М. Госпітальна терапія / за ред. Є.М. Нейка, Н.М. Середюк. - К.: Здоров я, 2006. - C. 315-319. 
2. Бондаренко Т.В. Особливості морфологічного стану слизової оболонки шлунка у хворих на виразкову хворобу дванадцятипалої кишки залежно від наявності та патогенності Helicobacter pylori / Т.В.Бондаренко // Сучасна гастроентерологія. - 2004. - № 4 (18). - С. 41-44.

3. Вдовиченко В.І. Вплив дуоденогастрального рефлексу на ефективність ерадикації гелікобактерної інфекції у хворих на виразкову хворобу дванадцятипалої кишки при застосуванні потрійної терапії / В.I. Вдовиченко // Гастроентерологія. - 2001. - № 32. - С. 196-199.

4. Горобець Н.М. Стабільні метаболіти оксиду азоту у хворих на артеріальну гіпертензію / Н.М. Горобець, В.К. Сєркова // Укр. терапевт. ж. -2005 . - № 2. - С. 22-24.

5. Поливода С.Н. Коррекция эндотелиальной дисфункции у больных гипертонической болезнью: эффективность и патофизиологическое обоснование применения тиотриазолина / С.Н. Поливода, А.А. Черенок, Р.В. Сычев // Актуальні питання фармацевтичної та медичної науки та практики. - Запоріжжя, 2002 , Вшт.УШ. - С. 193-196.

6. Гостищев В.К. Патогенез рецидиву гострих гастродуоденальних виразкових кровотеч / В.К. Гостищев, М.А. Євсєєв // Хірургія. 2004. - № 5. - C. 46-51.

7. Механізми розвитку дисфункції ендотелію та іiі роль у патогенезі ішемічної хвороби серця / О.О. Абрагамович, А.Ф. Файник, О.В. Нечай [та ін.] // Укр. кардіол. ж. - 2007. - № 4. - С. 81-87.

8. Агеев Ф.Т. Роль эндотелиальной дисфункции в развитии и прогрессировании сердечнососудистых заболеваний / Ф.Т. Агеев // Сердечная недостаточность. - 2003. - № 1. - С. 22-25.

9. Эндотелиальная дисфункция у больных с дебютом ишемической болезни сердца в разном возрасте / В.А. Алмазов, О.А. Беркович, М.Ю. Сытникова [и др.] // Кардиология. 2001. - T. 41, № 5. - С. 26-29.

10. Бабак О.Я. Артериальная гипертензия и ишемическая болезнь сердца - эндотелиальная дисфункция: современное состояние вопроса / О.Я. Бабак, Ю.Н. Шапошникова, В.Д. Немцова // Укр. терапевт. ж. - 2004. - № 1. - С. 14-21.

11. Білецький С.С. Ендотелійпротекторні властивості карведилолу у хворих 3 гострим інфарктом міокарда / С.С. Білецький // Укр. кардіол. ж. -2007 . - № 2. - С. 81-84.

12. Беленков Ю.Н. Эндотелиальная дисфункция при сердечной недостаточности: возможности терапии ингибиторами ангиотензинпревращающего фермента / Ю.Н. Беленков, В.Ю. Мареев, Ф.Т. Агеев // Кардиология. - 2001. Т. 41, № 5. - С. 100-104.

13. Ватутин Н.Т. Эндотелины и сердечнососудистая патология / Н.Т. Ватутин, Н.В. Калинкина // Укр. кардіол. ж. - 2006. - № 1. C. 101-106.

14. Визирь В.А. Роль эндотелиальной дисфункции в формировании и прогрессировании ар- териальной гипертензии. Прогностическое значение и перспективы лечения / В.А. Визирь, А.Е.Березин // Укр. мед. часопис. 2004. - № 4. - С. 23-33.

15. Гомазков О.А. Эндотелии в кардиологии: молекулярные, физиологические и патологические аспекты / О.А. Гомазков // Кардиология. 2001. - № 2. - С. 50-56.

16. Коркушко О.В. Эндотелиальная дисфункция / О.В. Коркушко, В.Ю. Лишневская // Кровообіг та гемостаз. - 2003. - № 2. - С. 4-15.

17. Маянская С.Д. Эндотелиальная дисфункция и острый коронарный синдром / С.Д. Маянская, А.Д. Куимов // Рос. кардиол. ж. - 2001. - № 2 (28). - С. 76-84.

18. Поливода С.Н. Влияние амлодипина на функцию эндотелия у больных с гипертонической болезнью: клинические эффекты и патофизиологические механизмы / С.Н. Поливода, А.А. Черепок, Р.А. Сычев // Укр. кардіол. ж. 2007. - № 4. - С. 46-49.

19. Полиморфизм генов NO-синтетазы и рецептора ангиотензина II 1-го типа и эндотелиальный гемостаз у больных ишемической болезнью сердца / Д.А. Затейщиков, Л.О. Манушкина, О.Ю. Кудряшова [и др.] // Кардиология. 2000. - Т. 40, № 11. - С. 28-32.

20. Клиническая значимость показателей эндотелиальной дисфункции, оксидативного стресса и гемостаза у больных инфарктом миокарда / О.Л. Барбараш, В.В. Кашталап, В.Н. Каретникова [и др.] // Патология кровообращения и кардиохирургия. - 2007. - № 2. - С. 28-33.

21. Братусь В.В. Оксид азота как регулятор защитных и гомеостатических реакций организма / В.В. Братусь // Укр. ревматол. ж. - 2003. № 4. - С. 3-11.

22. Концентрація ендотеліну-1 в плазмі крові корелює 3 вираженістю клінічних проявів стабільної стенокардії напруження / М.І. Лутай, В.А. Слободський, Т.І. Гавриленко [та ін.] // Укр. мед. часопис. - 2004. - № 4 (42). - С. 105-108.

23. Намаканов Б.А. Эндотелиальная дисфункция при артериальной гипертензии - фактор риска сердечно-сосудистых осложнений / Б.А. Намаканов, М.М. Расулов // Кардиоваскулярная терапия и профилактика. - 2005. - № 6. C. $98-101$.

24. Функция эндотелия и I/D-полиморфизм гена ангиотензинпревращающего фермента у больных эссенциальной гипертензией / А.Г. Полупанов, А.Н. Халматов, Н.Б. Ческидова [и др.] // Кардиология. - 2007. - Т. 47, № 6. - С. 54-55.

25. Семіотика та діагностика внутрішніх хвороб / В.М. Василюк та ін. // Фізичні методи обстеження / за заг. ред. В.М. Василюка. - 2-ге видання. - Тернопіль: ТДМУ, 2005. - С. 12-13.

26. Соловьев А.И. Клеточные механизмы гипертензии (артериальная гипертензия как эндотелиальная дисфункция и мембранная каналопатия) / И.А. Соловьев // Лікування та діагност. 2002. - № 1. - C. 9-13. 
27. Сыволап В.Д. Уровень эндотелина-1 при осложненном течении инфаркта миокарда / В.Д. Сыволап, В.В. Сыволап // Врач. дело. 2002. - № 2. - C. 139-140.

28. Черепок А.А. Клинико-прогностическое значение эндотелиальной дисфункции у больных гипертонической болезнью / А.А. Черепок / Укр. мед. альманах. - 2003. - Т. 6, № 3. C. $177-180$.

29. Vascular endothelial growth factor: the link between cardiovascular risk factors and microalbuminuria? / F.W. Asselbergs, R.A. de Boer, G.F. Diercks [et al.] // Int. J. Cardiol. 2004. - Vol. 93 (2-3). - P. 211-215.

30. Ferrara N. Vascular endothelial growth factor: basic science and clinical progress / N. Ferrara // Endocrin. Rev. - 2004. - Vol. 25. - P. 581-611.

31. Endothelins and endothelin receptor antagonists / S. Das, T.K. Mishra, C. Satpathy [et al.] // JIACM. - 2004. - № 5 (1). - P. 55-59.

32. Pasceri V. Direct proinflammatory effect of C-reactive on human endothelial cells / V. Pasceri, J.T. Willerson // Circulation. - 2000. Vol. 102. - P. 2165-2168.

33. O'Keefe J.H. Should an angiotensin-converting enzyme inhibitor be standard therapy for patients with atherosclerotic disease / J.H. O'Keefe, M.Wetzel, R.R. Moe // JACC. - 2001. - Vol. 37, № 1. - P. 1-8.

34. Angiogenesis in an in vivo model of adipose tissue development / J.G. Neels, T. Thinnes [et al.] // FASEB J. - 2004. - Vol. 18. - P. 983-985.
35. Dimmeler F. Endothelial cells apoptosis in angiogenesis and vessel regression / F.Dimmeler, A.M.Zeiher // Circulat. Res. - 2000. - Vol. 87. P. 434-444.

36. Vascular endothelial growth factor as a marker for early vascular damage in hypertension / W.C. Tsai, Y.H. Li [et al.] // Clin. Scin. - 2005. Vol. 109. - P. 39-43.

37. Involvement of serum vascular endothelial growth factor family members in the development of obesity in mice and humans / J. Gómez-Ambrosi, V. Catalán, A. Rodríguez [et al.] // J. Nutr. Biochem. - 2010. - Vol. 21 (8). P. 774-780.

38. Exercise training and endothelial dysfunction in coronary artery disease and chronic heart failure. From molecular biology to clinical benefits / S. Gielen, S. Erbs, G. Schuler [et al.] // Minerva Cardioangiol. - 2002. - Vol. 50. - P. 95-106.

39. Distinct characteristics of circulating vascular endothelial growth factors and $\mathrm{C}$ levels in human subjects / H. Wada, S. Ura. [et al.] // PLoS One. 2011. - Vol. 6. -6 p.

40. Association between vascular endothelial growth factor and hypertension in children and adolescents type I diabetes mellitus / K. Zorena1, J. Mys'liwska, M. Mys'liwiec [et al.] // J. Hum. Hypert. - 2010. - Vol. 24. - P. 755-762.

41. The relationship between vascular endothelial growth factor (vegf) and microalbuminuria in patients with essential hypertension / E.F. Ayerden, E. Haksun, D. B. Ulver [et al.] // Inter. Med. - 2008. - Vol. 47. - P. 1511-1516.

\section{НАРУШЕНИЕ ФУНКЦИОНАЛЬНОГО СОСТОЯНИЯ ЭНДОТЕЛИЯ ПРИ ЯЗВЕННОЙ БОЛЕЗНИ ЖЕЛУДКА И ДВЕНАДЦАТИПЕРСТНОЙ КИШКИ, СОЧЕТАННОЮ С МЕТАБОЛИЧЕСКИМ СИНДРОМОМ}

\section{А.И. Федив, И.А. Сицинская}

Резюме. В обзорной статье обобщены основные сведения о роли эндотелиальной дисфункции при язвенной болезни желудка и двенадцатиперстной кишки в процессе возникновения и становления метаболического синдрома. Приведены данные о влиянии эндотелиальных факторов на развитие ремоделирования сосудистой стенки при язве желудка и двенадцатиперстной кишки и метаболическом синдроме.

Ключевые слова: эндотелиальная дисфункция, перекисное окисление липидов, оксид азота, метаболический синдром, язвенная болезнь желудка, двенадцатиперстная кишка, гипертоническая болезнь, гипергликемия.

\section{IMPAIRED ENDOTHELIAL FUNCTIONAL STATE IN PATIENTS WITH PEPTIC ULCER AND DUODENAL ULCER COMBINED WITH METABOLIC SYNDROME}

\section{O.I. Fediv, I.O. Sitsinska}

Abstract. The principal information, dealing with the role of an endothelial dysfunction in case of peptic ulcer of the stomach and duodenum in the procces of origination and development of metabolic syndrome is generalized in a review paper.The findings, pertaining to the effect of endothelial factors on the development of remodeling the vascular wall in case of gastric and duodenal uncer and metabolic syndrome are submitted.

Key words: endothelial dysfunction, lipid peroxidation, nitric oxide, metabolic syndrome, peptic gastric ulcer, duodenum, essential hypertension, hyperglycemia.

Bukovinian State Medical University (Chernivtsi) 